\title{
An Enabling Mechanism for Subsidiary Autonomy
}

\author{
Lu-Jui Chen \\ Department of International Business, Ming Chuan University, Taiwan \\ Hung-Tai Tsou \\ College of Innovation and Entrepreneurship, Wenzhou University, China \\ Chun-Chung Chen \\ Department and Graduate Institute of International Business \\ National Taiwan University, Taiwan
}

Received: Jan. 8, 2019 Accepted: Oct. 14, $2019 \quad$ Published: January 1, 2020

doi:10.5296/jmr.v12i1.15595 URL: https://doi.org/10.5296/jmr.v12i1.15595

\begin{abstract}
Most studies discuss the mechanisms through which multinational enterprises (MNEs) empower their autonomy to their subsidiaries. However, how giving autonomy can promote one's absorptive capability is less investigated. In addition, the linked relationship is important for subsidiaries, but it also has a spillover effect. Based on this idea, this study analyzes the market conditions and springboard intentions as the reasons for subsidiary autonomy. We use data from subsidiaries that are located in Taiwan to test our contention. Our findings indicated that market conditions have positive impacts on empowering autonomy, and autonomy would allow subsidiaries to improve their knowledge absorption capacities. This study also verified the mediating effect of autonomy and the moderating effect of vertical integration quality. In general, our findings contribute to international enterprise and subsidiary management theory and have practical referential value for spillover effects and investment strategies.
\end{abstract}

Keywords: Autonomy, Springboard, Linkage, Spillover Effect 


\section{Introduction}

Multinational enterprises (MNEs) perceive overseas markets has become an important consideration in international strategies. Because many home markets of institutions restrict MNE operations, MNEs are required to make overseas direct investments (Luo \& Tung, 2007; Wu \& Chen, 2014). In this way, MNEs can access advanced markets to acquire higher-level knowledge capabilities and access emerging markets to acquire factors of production and markets (Shukla \& Mital, 2018), which will enable the MNEs to gain competitive advantages by expanding into global markets (Bartlett \& Ghoshal, 2002; Dikova et al., 2017; Dunning, 1993). Of course, some companies believe that only developed countries are worth entering. The only reason for entering emerging markets is to find potential markets that were not available in the past. Nevertheless, even in emerging markets, there is the potential for innovative knowledge to create new products and services for MNEs (Washburn \& Hunsaker, 2011). For example, GE's portable ultrasound technology, Intel's classmate PC, and Logitech's global product design center are good examples of companies using emerging markets' capabilities (Kumar \& Puranam, 2011; Washburn \& Hunsaker, 2011). Therefore, the conditions of overseas markets are attractive to MNEs. For example, market size, industrial settlements, geographical location, etc. can enable enterprises to overcome the difficulties that they face in their home countries. Overseas investments have become an important business behavior of MNEs (Grewal et al., 2008).

Many enterprises prefer to use risk assessments, focus on their core business and reduce transaction costs in response to overseas markets. The core idea behind these methods is often to stick to the occupancy first and seek rebirth from adversity later (Williamson \& Zeng, 2009). However, these practices provide limited help to today's MNEs. The relaxed regulations, reduced trade barriers, advanced information technology, changed population structure, and improved urbanization indicate that the business environment is not as stable as that in the past, and it experiences drastic changes. Therefore, when the environment changes, enterprises need to rely on the potential of their subsidiaries in the market and the subsidiaries need to become competitive units in the landlord market (Beugelsdijk et al., 2017; Taggart, 1997). The competitive advantages of enterprises come from their ability to transfer and absorb knowledge (Eisenhardt \& Martin, 2000; Gupta \& Govindarajan, 2000; Teece et al., 1997), especially for MNEs. The reason is that MNEs can effectively manage knowledge flows in global networks (Roth \& Morrison, 1992). Under these considerations, the management mode between headquarters and subsidiaries will affect how they can make full use of their advantages in the market, and it is also of great importance to the growth and survival of MNEs (Ramamurti \& Williamson, 2019). Furthermore, the management of the headquarters-subsidiary relationship will directly affect the benefits of the subsidiaries. Some headquarters believe that subsidiaries should be allowed to operate independently and are regarded as separate entities (Gates, 1995; Gates \& Egelhoff, 1986). Conversely, some headquarters believe that they should interfere in the day-to-day activities of their subsidiaries without delegating them any authority (Decreton et al., 2019). Therefore, how to address the autonomy of subsidiaries is crucial for MNEs.

Compared with subsidiaries that are highly controlled by their headquarters, autonomous subsidiaries are more efficient in completing the activities in the value chain (Jarillo \& Martinez, 1990). Previous studies have suggested that ownership advantages can be used to realize the benefits in the international market (Dunning, 1993) and, based on this, less attention is paid to subsidiary autonomy. However, when the market, environment, laws, regulations and political conditions rapidly change, and there is a management gap that is 
caused by institutional constraints and incompleteness (Khanna \& Palepu, 2010), MNEs need subsidiaries to compensate for the institutional voids in overseas markets (Schleimer \& Pedersen, 2013). At this time, enterprises will face the disadvantages from late market entry (Mathews, 2002; Sun et al., 2018), the lack of technology for organizing global activities, and even the negative effect of enterprise impression (Luo \& Tung, 2007). To reduce these uncertainties, subsidiaries can accumulate enterprise resources, reduce management costs and effectively respond to market demand to achieve enterprise performance when they have autonomy (Jerez-Gómez et al., 2019). Market conditions will make MNEs look at subsidiaries differently and change their empowered degree of autonomy. By empowering subsidiary autonomy, the management inefficiencies that are caused by the system gap can be prevented. In addition, the subsidiary can use a set of management methods that are different from the headquarters' operations, and the subsidiary can improve the legitimacy of its operations in the host country. Therefore, the traditional view of subsidiary autonomy should be further extended. The balance between control and efficiency is the factor that subsidiaries can use to absorb market capacity.

When subsidiaries are empowered with autonomy, they will be able to give full play to the benefits of absorptive capacity. Therefore, this study proposes several important achievements for empowering subsidiaries' autonomy. First, when subsidiaries have autonomy, it is equivalent to the larger decision-making space of the landlord state for responding to the local government (Doz et al., 2001). Because there are many potential market benefits in the landlord country, when subsidiaries are given the freedom to implement corporate strategies, they are more able to learn, integrate and commercialize multiple knowledge sources (Lane et al., 2001; Williamson \& Zeng, 2009), thus enabling subsidiaries to fulfill resource search tasks (Mathews, 2002; Song et al., 2005). Second, when a subsidiary has autonomy, it can be separate from its headquarters' system and administration. This is because headquarters often encounter institutional constraints in their home markets (Dunning, 1993). Empowering subsidiary autonomy can not only reduce the management damage that is caused by a bad headquarters system but also isolate the subsidiary from the negative effects that are caused by the system costs (Klepper, 1996). Due to the initiative nature of subsidiaries (Birkinshaw \& Fry, 1998), they can delegate responsibility, improve operational transparency, improve the governance system, and create corporate reputation among stakeholders (Jarillo \& Martinez, 1990; Luo \& Tung, 2007). Furthermore, the success of subsidiaries can be regarded as the interaction between the corporate strategy and the environment (Clark \& Ramachandran, 2019), and so empowering autonomy will enable subsidiaries to have the ability and independence to obtain more opportunities for cooperation with their landlord countries to complete value chain activities (Frost et al., 2002; Paterson \& Brock, 2002). Therefore, subsidiary autonomy enables managers to understand the constraints and challenges of home countries in the system and market.

Accordingly, this study mainly explores the antecedents of subsidiary autonomy and the impact of autonomy on absorptive capacity. Three contributions to subsidiary autonomy and management are proposed. First, we use the arguments of Glaister et al. (2003), Luo and Tung (2007) to illustrate the relationship between the degree of subsidiary autonomy based on market conditions and springboard intentions. Second, based on the argument that an enterprise should implement subsidiary autonomy (Filatotchev \& Piesse, 2009), this study indicates that vertical linkages can ease the effects of empowering autonomy. Third, under the organizational structure of the headquarters-subsidiary relationship, it is found that autonomy has a full mediating effect between empowering channels and absorptive capacity. 


\section{Literature review and hypothesis development}

\subsection{Subsidiary autonomy}

Autonomy refers to the extent to which a subsidiary can perform its tasks independent of the headquarters and other units under the authorization of the headquarters, and the extent to which the headquarters is allowed to freely make decisions (Glaister et al., 2003; Newburry \& Zeira, 1999). In the past, increasingly more attention was paid to the autonomy of subsidiaries, which is due to the shift of many studies from a focus on headquarters to a focus on subsidiaries (Paterson \& Brock, 2002; Song, 2014). Previous studies have focused on centralized management behavior and operational efficiency, and found that control is a source of competitive advantages for MNEs (Dadashpoor \& Yousefi, 2018). For example, when MNEs internationalize using global strategies, they use centralized management strategies to improve their efficiency and achieve economies of scale (Taggart, 1997). At that time, subsidiaries were regarded as implementers by enterprises. Basically, subsidiaries were viewed as the only links in enterprise value chains. Their main task is to help enterprises conduct large-scale production and efficiency improvements in overseas markets. At this time, they did not need too much self-awareness of their subsidiaries nor did they need subsidiaries to act beyond the requirements of the headquarters (Bartlett \& Ghoshal, 2002). However, this does not mean that the subsidiary's task as an executor is not important. Executors play a role in maintaining the survival of MNEs and supporting the enterprise strategy and innovation processes. Therefore, the efficiency of executives impacts MNEs. However, the centralized control of MNEs is often unsustainable. As enterprises enter increasingly more foreign markets, increasingly more subsidiaries are competing in markets with different operating environments. At this time, the centralized control of MNEs is becoming more inadequate (Paterson \& Brock, 2002). Because the headquarters cannot understand and grasp the large amount of market information and number of characteristics in detail, decision-making power begins to be decentralized to subsidiaries. The independence of subsidiaries has increased, and many business activities have begun to be able to be independently conducted (Jindra et al., 2009; Newburry \& Zeira, 1999) to promote performance and efficiency (Randolph \& Sashkin, 2002). Therefore, many studies focus on the importance of subsidiaries and network relations and discuss the benefits of managing subsidiaries (Andersson et al., 2002; Yamin \& Andersson, 2011). The core point of these studies is that subsidiaries have autonomy. When roles are different, autonomy has different effects on the strategic importance of subsidiary roles, such as knowledge innovators (Gupta \& Govindarajan, 2000), strategic leaders (Bartlett \& Ghoshal, 2002), advantage centers (Frost et al., 2002), mastering key social resources (Gulati et al., 2000) or the diffusion of network innovation (Birkinshaw et al., 2007), and all of these benefits originate from the autonomy of subsidiaries (Weng \& Cheng, 2019). Especially when the role of subsidiaries goes from paternalism to liberalism, subsidiary autonomy enhances efficiency and makes the distance between headquarters and subsidiaries an advantage, thus enabling subsidiaries to experiment with nontraditional and nonpopular projects. These projects were often rejected in the past, but often they were the driving forces for innovation. Therefore, the initiative and capacity development of subsidiaries need to be considered in management.

In the process of internationalization, some enterprises' overseas investments are in disadvantageous positions (such as backward markets, insufficient scales, weak brand reputations, etc.) or the subsidiary itself is in a fledgling stage. In this case, the traditional centralized control mode or the viewpoint of focusing solely on the network interests of subsidiaries is not enough to explain the importance of subsidiary autonomy. When 
subsidiary autonomy is focused on, the premise should be to explore whether subsidiaries have the characteristics of independence (Enright \& Subramanian, 2007; Newburry \& Zeira, 1999). Therefore, this paper starts from an MNE-centered viewpoint. It shows that the premise of empowering subsidiary autonomy comes from market conditions and a springboard strategy and that autonomy will result in management advantages for the subsidiary.

\subsection{Market conditions and autonomy empowerment}

The environment-strategy-performance analysis framework is based on the relations of many strategic choices. The argument is that the environment is the context of an enterprise's operations. Under the given background conditions, the enterprise should implement appropriate strategies to achieve the desired objectives (Chen et al., 2009; Schleimer \& Pedersen, 2013). More importantly, when implementing strategies, enterprises should pay more attention to the relationship between management mechanisms and environmental conditions. Many studies have found that in addition to the advantages that subsidiaries in host countries can bring to the growth of enterprises, the environment of the host country also affects the strategic choices of subsidiaries. The faster the environment changes and the more intense the competition is, the more aggregated the force that exists in the environment. If subsidiaries are regarded as the implementers of the global strategy of MNEs, in order to address this, the enterprise needs the subsidiaries to enact an aggressive integration strategy, and so it needs to fully authorize the subsidiaries' autonomy. Hada et al. (2013) pointed out that in order to be able to further grow in the host country, subsidiaries need to have committed relationships with local access partners. This committed relationship comes from the enterprise's globalization strategy, and, more importantly, the decision-making autonomy that establishes access relationships can be achieved. Bartlett and Ghoshal (2002) explore the operating characteristics of subsidiaries based on environmental complexity and local resources. They argue that as the environmental complexity and resource contents grow, output control or behavioral control become less applicable. Headquarters and subsidiaries need to effectively cooperate to regulate the subsidiaries by sharing shared values. To reduce the transaction and control costs of subsidiaries, the headquarters will increase the degree of subsidiary autonomy when the subsidiaries have more abundant market resources and are more closely embedded in society (Park \& Luo, 2001). Therefore, the more competitive the subsidiary is in the market, the more the subsidiary needs to communicate with local stakeholders, and we can use this relationship to understand the choice of the market and the customer segmentation that we need to achieve (Grewal et al., 2008). Thus, the subsidiary will formulate local marketing methods and planning strategies. That is, subsidiaries operating in a landlord country need autonomy to succeed in this market (Andersson et al., 2005).

Since the subsidiary management mechanism responds to the dynamic competitive conditions of the market, when a subsidiary wants to integrate appropriate marketing and management strategies for their market, the speed and efficiency depend on the degree of autonomy (Glaister et al., 2003). Doz and Prahalad (1981) argued that headquarters generally lack cognitive and managerial skills in unfamiliar environments and that headquarters understand that this will become a bottleneck in business growth. Therefore, the headquarters will understand that in more dynamic market conditions, even in unfamiliar environments, subsidiaries should be given greater autonomy. Many MNEs plan sets of exclusive control systems for different markets. However, no matter what kind of control system they have, they should grasp the principle that they should not be too involved in the decision-making 
processes of subsidiaries. As long as enterprise goals and norms can be integrated into the decision-making of subsidiaries, subsidiaries should be allowed to fulfill the tasks and responsibilities to be achieved (Lane et al., 2001; Newburry \& Zeira, 1999; Park \& Luo, 2001). The best way to have control and to make subsidiaries independent is to implement the best management mechanism (Randolph \& Sashkin, 2002). Therefore, this study proposes the following hypothesis:

\section{$H_{1}$ : The more competitive the market is, the more autonomous that subsidiaries will be.}

\subsection{International springboard}

There are many different reasons for MNEs to internationalize. Incentives such as motivations, activities, resource demand, market exploration and international expansion include both operational risks and competitive challenges. Many theories can be used to explain the process of internationalization, such as the compromise model (Dunning, 1993), the internationalized procedure model (Johanson \& Vahlne, 1990), the product life cycle (Klepper, 1996), the theory of substantive option, etc. The interpretation is based on the perspective of MNEs as a whole, and the role of subsidiaries cannot be highlighted in the internationalization process. Therefore, it triggers follow-ups such as those on network theory (Gulati et al., 2000), the springboard viewpoint (Luo \& Tung, 2007), and linkage-leverage-learn (Mathews, 2006), to deduce the behavior of subsidiaries.

This study considers that the springboard strategy of MNEs is of great importance to the development of enterprises. According to Luo and Tung (2007), MNEs (especially those from emerging countries) use overseas investments as springboards to obtain global resources and abilities in the face of global competition or to avoid the influence of their home country's system and market restrictions. The springboard intentions of enterprises reduce backward disadvantages and create competitive advantages in markets by means of positive actions and the pursuing abilities. For example, by acquiring technological capabilities through mergers and acquisitions and expanding resources and technologies through joint ventures, these springboard strategies allow one to catch up with benchmark enterprises in the market, and they also provide a systematic and planned long-term strategy to enable enterprises to improve their competitive positions. Therefore, in terms of the entry mode and location selection, a springboard strategy is usually not a path-dependent or evolutionary selection process, but rather it comes from the strong global competitors in the market, rapid changes in technology and products, the limitations of domestic systems, and the market demand control in key enterprises. Furthermore, when global competitors (or successful MNEs in advanced countries) want to sell or share resources, a springboard strategy can help enterprises to rapidly integrate into the global economy and become part of the global product supply chain. For example, Lenovo's acquisition of Motorola has formed an important competitor in the smart phone market, and $\mathrm{AB}$ InBev's incorporation of Heineken into PepsiCo's operations and plans to invest in PepsiCo's operations in the future indicate that companies are behaving quite differently when they invest overseas. Filatotchev and Piesse (2009) pointed out that entrepreneurship enterprises need vast funds and resources to expand internationally. Especially for new enterprises, when they are short of resources and funds, they often need to obtain basic resources through IPOs. This will allow them to increase their R\&D density and exports through internationalization, and then promote enterprise growth in international and domestic markets. This also occurs because new enterprises have entrepreneurship orientations, which make them more willing to take risks than traditional enterprises, and they also have advantages when learning new things (Autio et al., 2000). 


\section{$\triangle$ Macrothink}

Journal of Management Research

ISSN 1941-899X 2020, Vol. 12, No. 1

The springboard strategy is when enterprises have different activities for different purposes, such as mergers and acquisitions, in order to make up for the lack of resources and reputation. When purchasing suppliers or channels, enterprises can adjust their bargaining power and revolve around each other when facing customers, and this forms the recursive behavior between the investments in the landlord country and the activities in the home country (Chen et al., 2009; Luo and Tung, 2007). Therefore, MNEs regard international expansion as a springboard strategy that can be accomplish several goals, as follows: to complement competitive disadvantages; overcome backward disadvantages and multipoint competition with competitors; avoid trade barriers; ease restrictions on home country system; ensure preferential and preferential government support in the host country market, emerging markets and open markets; and take advantage of its competitive advantages in developing markets (Bartlett \& Beamish, 2013; Washburn \& Hunsaker, 2011). Generally, the motivation behind MNEs using a springboard strategy can be summarized as resource and opportunity seeking. By expanding to overseas markets, it can improve its economies of scale and scope in the home market while simultaneously filling the gaps and deficiencies in its competitiveness. Therefore, when MNEs expand, they often use subsidiaries to authorize or conduct joint ventures with competitive enterprises in local markets to learn complex management procedures and product technology from them, which then allow subsidiaries to better adapt and modify their relationships with the target markets (Khanna \& Palepu, 2010; Song, 2014 2014).

\subsection{Springboard intention and autonomy empowering}

The strategic choice of subsidiaries in overseas markets reflects the global strategy of MNEs and the headquarters' supervision and evaluation of whether subsidiaries achieve global strategic objectives (Doz \& Prahalad, 1991). Therefore, many studies focus on the view that the role of subsidiaries lies within the organization. Bartlett and Ghoshal (2002) believe that when the headquarters' knowledge of overseas management is limited, it will increase its commitment to overseas markets, improve the autonomy of subsidiaries to respond to local conditions, and hope that subsidiaries can accumulate experience and transfer it to the enterprise. When Doz and Prahalad (1991) studied the innovation behavior within MNEs, they believed that innovation came from the initiative behavior, which could motivate subsidiaries to engage in innovation behavior if it could be permitted by management. Therefore, for MNEs, not only the headquarters' control should be loose but also the subsidiary's autonomy should be empowered if the subsidiary is expected to grow in the process (Hada et al., 2013; Teece et al., 1997).

According to Luo and Tung (2007), the overseas investment behavior of MNEs is the intention to use a springboard strategy. Especially in emerging markets, MNEs often face the restrictions of their home market system and growth. They can reduce operating costs and expand profits by investing in overseas markets. Based on the definition of Luo and Tung (2007), this study argues that MNEs will use systematic and repeated international expansion and investment behaviors as springboards to make up for the lack of resources and capabilities, viewing each investment as a starting point for growth. When enterprises have the intentions to use a springboard strategy, they need a set of internationalization mechanisms that can improve their competitive advantages. However, due to the lack of resources and capabilities and the inability to comprehensively interpret global market information, MNEs are unable (or unwilling) to fully meet the international needs of all overseas markets in their home countries. However, these resource demand gaps can be supplemented by knowledge and capabilities that are spread across the global market, and so 


\section{Mll Macrothink}

Journal of Management Research

ISSN 1941-899X

2020, Vol. 12, No. 1

MNEs will use various entry modes to achieve this goal. For example, enterprises can quickly acquire market shares and technology through mergers and acquisitions, shape market operating conditions through alliances, expand their market shares through authorization and franchising, set up factories to directly avoid trade barriers, etc. (Andersson et al., 2002; Gates \& Egelhoff, 1986; Johanson \& Vahlne, 1990; Khanna \& Palepu, 2010; Mathews, 2006). Wang et al. (2014) argued that when an enterprise wants to link the business content between the home country and the host country, it will empower subsidiaries with some autonomy to establish local relations. That is, by entering advanced or emerging markets, enterprises can find important complementary resources and new market opportunities (Autio et al., 2000; Dunning, 1993). The main motivation of international expansion is to explore and exploit the global market (He \& Wong, 2004; Phene et al., 2012). The success of these two events depends on whether the subsidiary can achieve its task in an uncertain, risky and complex environment (Bartlett \& Beamish, 2013). Therefore, enterprises need mechanisms to ensure and support the operations of subsidiaries but also need to enable subsidiaries to remain responsive in unfamiliar environments.

Enterprises should ensure that an important mechanism for operating in the host country market is to grant subsidiaries autonomy, which means that subsidiaries have more flexibility and decision-making space when facing uncertainty and need to explore environmental tasks in depth. In the process, if the headquarters intends the subsidiary to be able to commission products and penetrate the market, it should give the subsidiary $\mathrm{R} \& \mathrm{D}$, manufacturing and marketing powers in the industrial value chain. Furthermore, headquarters should give subsidiaries the opportunity to formulate valuable strategies to further increase the power of subsidiaries (Birkinshaw, 1997). That means that subsidiaries can respond to the market by taking action (Birkinshaw et al., 2007). Considering that MNEs use international expansion and investment as springboards to increase their competitive advantages, this study proposes the following hypothesis:

\section{$\mathrm{H}_{2}$ : The more obvious the springboard intentions of MNEs are, the more autonomous the subsidiaries will be.}

\subsection{Autonomy empowerment and absorptive capacity}

An organizational management mechanism can induce many knowledge-related activities, such as knowledge evaluation, absorption, integration, application, and commercialization. These activities will affect the knowledge processing processes in enterprises (Gupta \& Govindarajan, 2000). In the past, some studies did not take the influence of organizational mechanisms into account when discussing absorptive capacity. For example, Cohen and Levinthal (1990) did not consider whether organizational mechanisms could be used as the premise of absorptive capacity. Zahra and George (2002) seldom discuss what organizational factors are more effective or how to increase absorptive capacity. However, organizational mechanisms impact absorptive capacity, especially for MNEs. It is essential for subsidiaries to have access to key knowledge resources in landlord countries through different management mechanisms (Frost et al., 2002; Khanna \& Palepu, 2010). According to the dynamic capability view, continuous learning is the key to maintaining unique competitiveness (Teece et al., 1997). Global learning is the strategic requirement for MNEs to win international competitive advantages (Ghoshal \& Bartlett, 1990). Because of the correlation between absorptive capacity and the enterprise management mechanism, this hypothesis focuses on the influence of the degree of autonomy that is given to subsidiaries on absorptive capacity. 
In the context of transnational business, empowering subsidiary managers can effectively improve efficiency and learning outcomes (Randolph \& Sashkin, 2002). Because the knowledge of landlord countries can help enterprises to adjust and coordinate the effectiveness of their global strategies, improve the network relationships between units, and fill the knowledge gap between new products and technologies, subsidiaries need decision-making space to grasp the location's interests. The hierarchical structure of MNEs will affect the autonomy of subsidiaries (Birkinshaw, 1997), but as the coordination and horizontal communication channels become increasingly more pluralistic, the problem of centralization will not increase the management burden in MNEs (Taggart, 1997). Because there is a close relationship between decision-making power and absorptive capacity (Glaister et al., 2003), just as an organization's operational efficiency is highly correlated with its absorptive capacity (Gates \& Egelhoff, 1986), empowerment is closely related to the diversity of the knowledge structure and the input mode within the organization (Zahra \& George, 2002). Based on the research of MNEs, it is found that when subsidiaries can obtain decision-making power, they can enhance their abilities to develop new knowledge (Mathews, 2002; Park \& Luo, 2001). Whether a partner is in the landlord market or a group enterprise, the greater the authorization is, the larger the ability of the subsidiary to achieve deeper cooperative relationships (Andersson et al., 2005). When the knowledge pool is more diversified, subsidiary learning will be more stable, the new and old knowledge will be effectively integrated and applied, and the new knowledge will be suitable for enterprise development (Birkinshaw \& Fry, 1998; Cohen \& Levinthal, 1990; Schleimer \& Pedersen, 2013). Therefore, the more autonomous a subsidiary's business activities are, the more that they can combine different knowledge to produce valuable capabilities (Almeida \& Phene, 2004). Newburry and Zeira (1999) argued that when a subsidiary can execute its exclusive strategic business plan independently, it can not only access valuable knowledge sources but also effectively manage and absorb relevant knowledge. Therefore, this study proposes the following hypothesis:

\section{H3: The more autonomous a subsidiary is, the greater its absorptive capacity will be.}

\subsection{The moderating role of vertical linkages}

Past studies on internationalization have used a static strategic point of view to infer how MNEs develop their unique resources and competitive advantages in their host countries (Dunning, 1993). However, with the increasingly fierce competition in the global market, market profits will continue to be affected by the actions of competitors and changes in environmental factors. Teece et al. (1997) advocated that enterprises should strive to restructure new knowledge, invest in the relationship between the acquisition and adoption of new capabilities, and continuously expand resources into new competitive areas by improving management processes to enhance their competitive advantages. Therefore, the international expansion of MNEs uses existing resources for cross-border transfer and further acquires local necessary resources to develop their capabilities (Frost et al., 2002 2002; Grewal et al., 2008). Luo and Tung (2007) argued that when MNEs expand internationally across borders, they must effectively allocate value chain activities to achieve success. In the active area of the allocation value chain, linking and cooperating with each other to integrate the relationship between the upstream and downstream is the key to gaining advantageous advanced technology, high operational efficiency and market demand (Andersson et al., 2002; Gulati et al., 2000; Kumar \& Puranam, 2011).

When competitive pressures increase, subsidiaries will experience linkage risks. In a highly competitive environment, enterprises will be particularly worried about whether knowledge 
will be learned by competitors since knowledge has spillover risks (Liu et al., 2014). The imperfect appropriability of knowledge, coupled with the contact and exposure of knowledge transfer and its application to cooperation, can easily lead to spillovers to other enterprises (Almeida \& Phene, 2004). The potential costs of knowledge's quasi-public property will hinder the value creation ability of overseas subsidiaries. Although the value of knowledge can be protected by patent laws, the inability to enforce the protective intangible asset ownership regulations, the failure to effectively protect the confidentiality of R\&D and innovation processes, or reverse engineering will lead to the duplication and imitation of enterprise products, technologies or processes, which will reduce their value (Perri et al., 2013). In fact, knowledge spillovers often occur during international expansion. Overseas direct investment is a potential important channel for knowledge diffusion (Santangelo, 2012). Yamin and Andersson (2011) pointed out by demonstrating new technologies or employee training that companies can transfer management or marketing skills to overseas subsidiaries. In this case, knowledge spillovers between related industries may occur if subsidiaries have repetitive networks of landlord suppliers or downstream vendors that are similar to their headquarters. As the links between subsidiaries and their upstream and downstream affiliated enterprises become wider, competitors or external enterprises will actively imitate and learn based on market profitability and even improve their innovation ability by investing (Liu et al., 2014).

Although knowledge spillover may occur in vertical and horizontal linkages, the spillover effects that are caused by vertical linkages are wider and more uncontrollable. The reason is that these upstream and downstream enterprises themselves also have multiple linkages. When knowledge spills over to these suppliers or customers, even if these enterprises are unable to grasp the value of knowledge, they may intentionally or unintentionally shift the knowledge to their direct or indirect competitors (or even potential entrants) in the market. Therefore, the more intense the competition is, the better the quality of the market connection, and the more likely it is to cause knowledge spillover risk (Perri et al., 2013). The knowledge spillover risk from these subsidiaries negative impacts FDI intentions, the examination of market conditions, and the expansion of subsidiaries' autonomy. Therefore, this study proposes the following hypotheses:

H4: The positive relationship between market conditions and the empowerment of subsidiary autonomy will be weakened by the combination of vertical linkages, and

H5: The positive relationship between springboard intentions and the empowerment of subsidiary autonomy will be weakened by the combination of vertical linkages.

\section{Methodology}

\subsection{Sample}

The research object of this paper is foreign subsidiaries in Taiwan. There are 65 international subsidiaries (American enterprises account for the majority, and there are other countries such as Britain, France, etc.) and 53 Asian enterprises, with Japan and China as the majority. Subsidiaries represent MNEs' business strategies, overseas investment behavior, and landlord environments (Andersson et al., 2005; Birkinshaw et al., 2007; Gupta \& Govindarajan, 2000; Williamson \& Zeng, 2009). In addition, subsidiary autonomy is the freedom and space that the headquarters gives to subsidiaries for decision-making. On the other hand, subsidiaries are more aware of the value and costs of internal linkages (Andersson et al., 2002; Glaister et al., 2003). Using subsidiaries as sample units can theoretically represent the strategic viewpoints of subsidiaries when they operate in their host countries and use qualitative 
method to analyze all hypotheses.

In the data collection, because it is not easy to observe a strategy using objective data, a questionnaire is the most suitable means for collecting perceptual data, and it is also highly correlated with the objective measurement data (Newburry \& Zeira, 1999; Park \& Luo, 2001; Yamin \& Andersson, 2011). Therefore, self-administered questionnaires are used and the questions are measured using a Likert scale. The questionnaire mainly comes from the literature review and the opinions of business managers to form measurement questions (see the Appendix). The sample sources are mainly from the "List of Foreign Investment" that was published by the Investment Review Committee of the Taiwan Ministry of Economy (information on the investment units of foreign enterprises in Taiwan). The samples are selected using the systematic sampling method. In addition, using Taiwan as a single landlord for subsidiary operations allows us to focus on the impacts of the environment and control the impact of location on subsidiary strategy. Through repeated questioning and retrieval, samples with incomplete or incomplete data were excluded, and enterprises that had not yet returned questionnaires were reissued questionnaires or eliminated through telephone contact. A total of 126 questionnaires were recovered. After that, eight invalid questionnaires were excluded, and 118 valid samples were obtained with a response rate of $9.8 \%$. Although the sample response rate is low, the expected mail response rate for large samples is usually $5-20 \%$, and so the response rate is acceptable (Dikova et al., 2017).

The distribution of industries that invested in this sample is mostly concentrated in the technology and electronics industry (54), the service industry (39) and traditional industry (25). Most of the subsidiaries have been invested in Taiwan for 5-15 years, most of which are concentrated in the range of 5-10 years (39) and 10-15 years (29). To ensure the representativeness of the samples, the t-test is used to verify the nonresponse bias for the nationality, scale and question items of the early and late recovered samples (Cui et al., 2018). The results showed that there was no significant difference, indicating that the samples were representative.

\subsection{Measures}

Market conditions were based on the Luo and Park (2001) and Chen et al. (2009) and are used to explore the degree of market variability and competitiveness of subsidiaries. Subsidiary autonomy was based on Gate and Egelhoff (1986) and Glaister et al. (2003). The measurement emphasizes the degree of operational and strategy formulation power that headquarters give to subsidiaries rather than the intentions of subsidiaries' active actions. Springboard intention was based on Luo and Tung (2007) and was used to illustrate that MNEs repeatedly and systematically use international expansion as a springboard to access advanced technology, gain brand benefits, improve their international reputation, and acquire knowledge and manpower. In terms of absorptive capacity, this study considers that absorptive capacity is the incorporation of nonexistent knowledge into activities and includes three directions: identification, understanding and application. Therefore, in addition to Cohen and Levinthal (1990) and Zahra and George (2002), the three subconstructs of Schleimer and Pedersen (2013) are used to construct the absorptive capacity. Vertical linkages were based on Andersson et al. (2002) to measure the degree of interdependence between subsidiaries and the breadth of the direct linkages between the upstream and downstream (Note 1). All questionnaires are listed in the Appendix and are measured using five-point Likert scales. AMOS was used for the confirmatory factor analysis and structural model validation. To test the moderating effect of vertical linkages, the question measurements incorporated the questions on market conditions and springboard intentions 
into the analysis to avoid the problem of multicollinearity (Efrat et al., 2018).

The data of this study are from subsidiaries, and subsidiaries can indeed answer the information related to the headquarters (Wang et al., 2014). Two methods are used to detect common method bias. First, we used Harmon's one-factor test (Podsakoff \& Organ, 1986) to examine the presence of common method bias. In our analysis of the samples, no single factor emerged. The first factor accounted for $23.59 \%$ of the total variance, and the seven extracted factors accounted for $79.4 \%$ of the variance. Second, the correlation matrix (see Table 1) did not indicate any highly correlated variables while evidence of common method bias usually results in extremely high correlations ( $\mathrm{r}>0.90)$ (Bagozzi et al., 1991). These figures suggest that our results were not due to common method bias.

\section{Data analysis and results}

\subsection{Measurement properties}

The reliability was evaluated by using the composite reliability (CR). The CR values should be higher than 0.7 for reliable measures (Fornell \& Larcker, 1981). The CR values all exceeded 0.7 , ranging from 0.80 to 0.98 , which indicated that the measures were reliable. The convergent validity was examined using the average variance extracted (AVE). The AVE values should be above the recommended level of 0.5 (Fornell \& Larcker, 1981). These variables were indeed all above 0.5 , ranging from 0.50 to 0.92 . In addition, the value of the square root of the AVE for each variable in the diagonal was higher than the value in the corresponding off-diagonal, which indicated that the discriminant validity was satisfactory. The properties of the measurement model are summarized in Table 1.

Table 1. Mean, SD, AVE, CR and correlations

\begin{tabular}{llllllllllll}
\hline Construct & Mean & SD & AVE & CR & (1) & (2) & (3) & (4) & (5) & (6) & (7) \\
\hline Market conditions (1) & 20.00 & 3.01 & 0.73 & 0.92 & 0.85 & & & & & & \\
Springboard intention (2) & 15.39 & 3.04 & 0.50 & 0.80 & $0.55^{* *}$ & 0.71 & & & & & \\
Subsidiary autonomy (3) & 27.54 & 5.36 & 0.79 & 0.95 & $0.48^{* *}$ & $0.30^{* *}$ & 0.89 & & & & \\
Knowledge identification (4) & 10.99 & 2.77 & 0.75 & 0.90 & $0.35^{* *}$ & 0.13 & $0.58^{* *}$ & 0.87 & & & \\
Knowledge understanding (5) & 11.30 & 2.68 & 0.71 & 0.88 & $0.29^{* *}$ & 0.13 & $0.59^{* *}$ & $0.40^{* *}$ & 0.84 & & \\
Knowledge application (6) & 11.05 & 2.69 & 0.61 & 0.82 & $0.42^{* *}$ & $0.20^{* *}$ & $0.60^{* *}$ & $0.34^{* *}$ & $0.43^{* *}$ & 0.91 & \\
Vertical linkages (7) & 11.23 & 5.09 & 0.92 & 0.98 & $0.52^{* *}$ & $0.27^{* *}$ & $0.63^{* *}$ & $0.61^{* *}$ & $0.53^{* *}$ & $0.60^{* *}$ & 0.96 \\
\hline
\end{tabular}

Notes: a) $* * \mathrm{p}<0.05$; b) The numbers on the diagonal are values of the square root of the AVE

\subsection{Second-order construct of absorptive capacity}

Absorptive capacity is a second-order reflective construct that consists of three first-order constructs: knowledge identification, knowledge understanding, and knowledge application. The second-order model statistics showed that the $\chi 2=54.41$ (d.f. $=24)$, GFI $=0.91$, AGFI $=$ 0.83 , RMSEA $=0.077$, NFI $=0.92, \mathrm{IFI}=0.96$, and $\mathrm{CFI}=0.96$, and the indicators are in line with Bollen's (1989) recommendations. From Table 2, the factor loadings of the first-order constructs are significant, and the paths between the first-order constructs and the second-order construct are also significant. To confirm that three first-order constructs can be integrated into absorptive capacity, based on Jayachandran et al. (2005), this study used the average scores of three first-order constructs as indicators for one-factor confirmatory factor 
analysis. The results show that the path coefficients are significant (Table 2), which indicates that the absorptive capacity can be used for follow-up analysis with the second-order construct.

Table 2. Second-order confirmatory factor analysis (CFA)

\begin{tabular}{|c|c|c|c|c|c|}
\hline Construct & Variable & Factor loading & $\begin{array}{c}\text { Standard } \\
\text { error }\end{array}$ & T-value & P-value \\
\hline \multirow{3}{*}{$\begin{array}{l}\text { Knowledge } \\
\text { identification }\end{array}$} & Y1 & 0.82 & & & \\
\hline & Y2 & 0.87 & 0.10 & 10.97 & 0.00 \\
\hline & Y3 & 0.91 & 0.10 & 11.39 & 0.00 \\
\hline \multirow{3}{*}{$\begin{array}{l}\text { Knowledge } \\
\text { understanding }\end{array}$} & Y4 & 0.94 & & & \\
\hline & Y5 & 0.78 & 0.08 & 10.27 & 0.00 \\
\hline & Y6 & 0.79 & 0.09 & 10.48 & 0.00 \\
\hline \multirow{4}{*}{$\begin{array}{l}\text { Knowledge } \\
\text { application }\end{array}$} & Y7 & 1.04 & & & \\
\hline & Y8 & 0.68 & 0.08 & 8.40 & 0.00 \\
\hline & Y9 & 0.77 & 0.07 & 10.39 & 0.00 \\
\hline & $\begin{array}{l}\text { Knowledge } \\
\text { identification }\end{array}$ & 0.51 & & & \\
\hline \multirow[t]{2}{*}{$\begin{array}{l}\text { Absorptive } \\
\text { capacity }\end{array}$} & $\begin{array}{l}\text { Knowledge } \\
\text { understanding }\end{array}$ & 0.79 & 0.56 & 3.18 & 0.00 \\
\hline & $\begin{array}{l}\text { Knowledge } \\
\text { application }\end{array}$ & 0.57 & 0.43 & 3.56 & 0.00 \\
\hline
\end{tabular}

Factor analysis by mean score method

\begin{tabular}{|c|c|c|c|c|c|}
\hline \multirow{3}{*}{$\begin{array}{l}\text { Absorptive } \\
\text { capacity }\end{array}$} & $\begin{array}{l}\text { Knowledge } \\
\text { identification }\end{array}$ & 0.56 & & & \\
\hline & $\begin{array}{l}\text { Knowledge } \\
\text { understanding }\end{array}$ & 0.71 & 0.33 & 3.70 & 0.00 \\
\hline & $\begin{array}{l}\text { Knowledge } \\
\text { application }\end{array}$ & 0.60 & 0.27 & 3.91 & 0.00 \\
\hline
\end{tabular}

\subsection{Results for the structural model}

The constrained model includes the direct relationship between market conditions, springboard intentions, autonomy and absorptive capacity, while the unconstrained model uses a moderating variable with vertical linkages. From Table 3, there were significant differences in Chi-square between models $\left(\mathrm{p}<0.01\right.$ ) (CFA vs. constrained model $\Delta \chi^{2}=85.98$, CFA vs. unconstrained model $\Delta \chi^{2}=2143.04$, and constrained model vs. unconstrained model $\Delta \chi^{2}=2657.06$ ). Therefore, the unconstrained model with moderator variables can be used for the hypotheses testing (Efrat et al., 2018). Table 3 illustrates the model fit of the research model and the verification of both the constrained and unconstrained models. 
Table 3. Model fit

\begin{tabular}{lllllllll}
\hline & $\chi 2(\mathrm{df})$ & $\chi 2 / \mathrm{df}$ & $\mathrm{p}$ value & GFI & RMSEA & TLI & CFI \\
\hline CFA & $236.51(101)$ & 2.34 & 0.00 & 0.93 & 0.05 & 0.87 & 0.89 \\
Constraint model & $322.49(104)$ & 3.18 & 0.00 & 0.88 & 0.07 & 0.84 & 0.82 \\
Unconstraint model & $2979.55(344)$ & 8.66 & 0.00 & 0.82 & 0.08 & 0.82 & 0.80 \\
\hline
\end{tabular}

Notes: CFA: confirmatory factor analysis; Constraint model: Structural model includes independent variables (and set path relationships to be the same); Unconstraint model: Structural model includes independent variables and moderator variable)

Table 4 shows the results of hypotheses analysis (Note 2). Market conditions have a significant positive relationship with subsidiary autonomy $(\beta=0.18 ; \mathrm{p}<0.01)$. Relative to $\mathrm{H} 1$, market conditions are significantly negative when considering the effect of vertical linkages $(\beta=-0.70 ; \mathrm{p}<0.01)$, thus supporting H4. Next, springboard intentions have a significant negative relationship with subsidiary autonomy. $(\beta=-0.05 ; p<0.05)$, showing that $\mathrm{H} 2$ is not supported. However, the effect of adding vertical linkages was significantly positive $(\beta=0.16 ; p<0.01)$, and although it was to ease the negative relationship between the two variables, H5 was not supported. The relationship between subsidiary autonomy and absorptive capacity shows a significant positive relationship $(\beta=1.04 ; \mathrm{p}<0.01)$, and thus $\mathrm{H}_{3}$ was supported. Accordingly, the hypothesis is supported by empirical evidence, which shows that the theoretical model has explanatory power. Although the result of springboard intentions is significant, it is not consistent with the inference. This study proposes that market conditions and springboard intentions will affect the increase of autonomy, while autonomy will affect the knowledge absorption capacity of subsidiaries. To confirm the mediating effect of autonomy, this paper refers to Zhang et al. (2019) and uses the Sobel test to verify the mediating effect (Hughes et al., 2014). From Table 5, the indirect effect of autonomy is significant, indicating that autonomy is a full mediating variable.

Table 4. Results of unconstraint model of structural model

\begin{tabular}{lcc}
\hline \multicolumn{1}{c}{ Construct } & Subsidiary autonomy (t-value) & Absorptive capacity (t-value) \\
\hline Independent variables & & - \\
Market conditions $\left(\mathrm{H}_{1}\right)$ & $0.18(11.55)^{* *}$ & - \\
Springboard intention $\left(\mathrm{H}_{2}\right)$ & $-0.05(-3.08)^{*}$ & $1.04(9.53)^{* *}$ \\
Subsidiary autonomy $\left(\mathrm{H}_{3}\right)$ & - & - \\
& & \\
Moderator variables & $-0.70(-40.61)^{* *}$ & - \\
Market conditions x Vertical & & \\
linkages $\left(\mathrm{H}_{4}\right)$ & $0.16(10.71)^{* *}$ & \\
Springboard intention x Vertical & & \\
linkages $\left(\mathrm{H}_{5}\right)$ & &
\end{tabular}




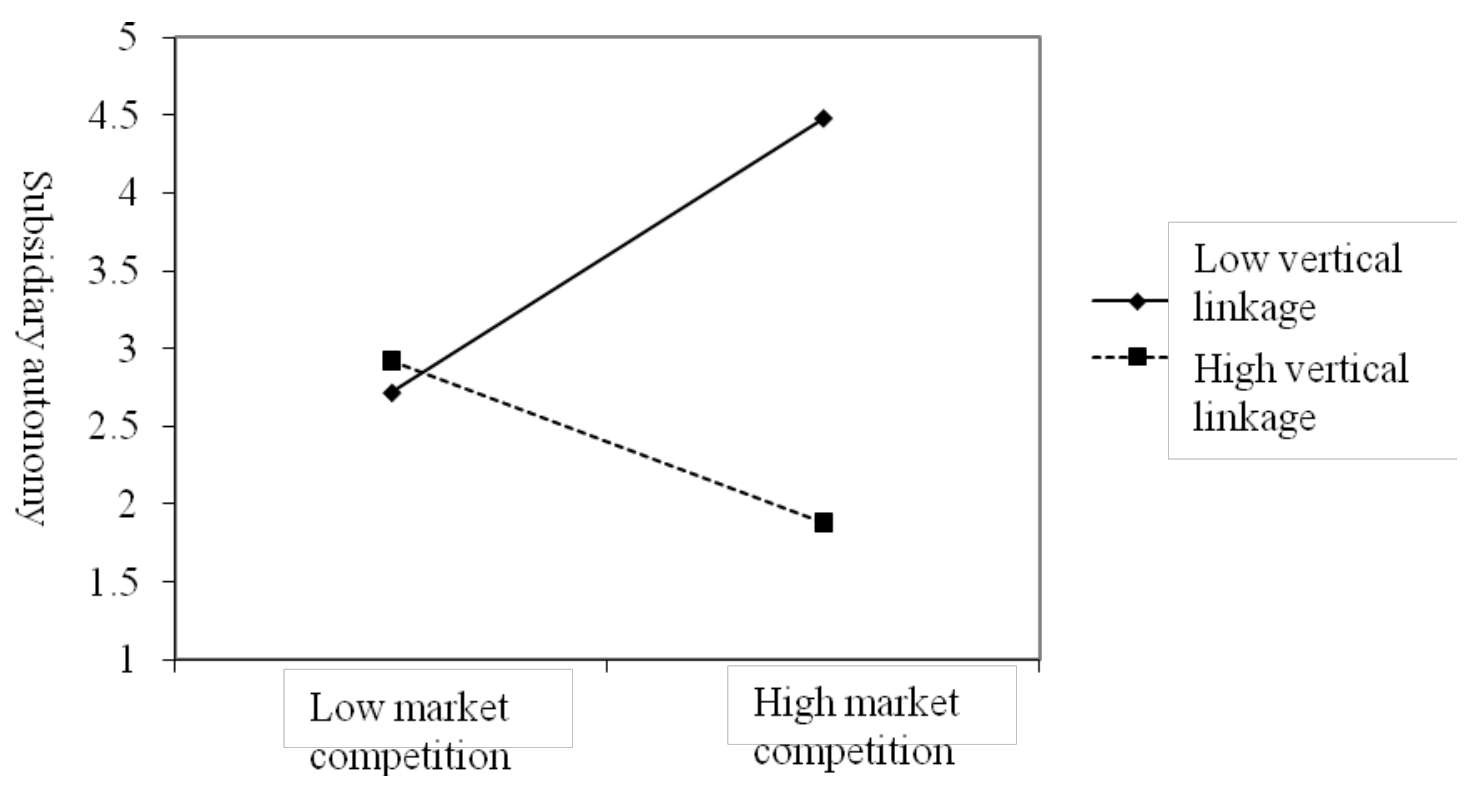

Figure 1: Interaction of vertical linkages and market competition on subsidiary autonomy

Table 5. Results for mediating effects (Sobel test)

\begin{tabular}{|c|c|c|c|c|c|c|c|c|}
\hline Path & $\mathrm{a}$ & $\mathrm{SE}_{\mathrm{a}}$ & $\mathrm{b}$ & $\mathrm{SE}_{\mathrm{b}}$ & $\mathrm{Z}$ & $\mathrm{c}$ & $\begin{array}{c}\text { Indirect } \\
\text { effect }\end{array}$ & $\begin{array}{c}\text { Effect } \\
\text { ratio }\end{array}$ \\
\hline $\mathrm{MC} \rightarrow \mathrm{SA} \rightarrow \mathrm{AC}$ & 0.86 & 0.14 & 0.82 & 0.07 & $5.11 * *$ & 0.25 & 0.70 & 2.82 \\
\hline $\mathrm{SI} \rightarrow \mathrm{SA} \rightarrow \mathrm{AC}$ & 0.53 & 0.16 & 0.90 & 0.07 & $3.23 * *$ & -0.08 & 0.47 & 5.96 \\
\hline
\end{tabular}

\section{Discussion and conclusions}

The purpose of this study is to determine whether subsidiaries will first influence the degree of autonomy and then the absorptive capacity of subsidiaries because of market conditions and springboard intentions. The results indicated that subsidiary autonomy is the key point. Considering the market competition and dynamics, if subsidiaries want to have absorptive capacity, the degree of autonomy should be considered by MNEs, which echoes Glaister et al. (2003). Subsidiaries' autonomy often depends on market competition and the extent to which they intend to execute the springboard strategy (Hada et al., 2013; He \& Wong, 2004). When autonomy exists, subsidiaries are free to make decisions to determine the extent to which they need to absorb external capabilities. From the view of the mediating effect, the affirmation of the absorptive capacity is to be carried out only when the subsidiary has autonomy. By definition, autonomy means the degree to which subsidiaries are free to make decisions without the permission of their headquarters. Therefore, the importance of autonomy lies in being able to play a key role in balancing the development strategy of subsidiaries. When it is confirmed that autonomy has a full mediating effect, it shows that autonomy is not only an independent commandment by MNEs but also an important strategy to assist in the 
construction of business models. Further, market conditions and springboard intentions have significant effects on subsidiary autonomy. However, market conditions have a positive effect while springboard intentions have a negative effect. In addition, the vertical linkages have significant weakening effects on the direct relationships.

\subsection{Theoretical implications}

First, according to Randolph and Sashkin (2002), when a subsidiary is in a competitive and dynamic market, for the subsidiary to be able to respond to market needs, it is necessary to give the subsidiary decision-making autonomy, which allows external capabilities to be absorbed to reduce uncertainty and threats (Cohen \& Levinthal, 1990). Because of globalization, enterprises not only need much diversified production but also face demand continuity changes, which changes management quality. It is traditionally customary to run subsidiaries using centralized or decentralized management, but such management has been unable to enable subsidiaries to be effective. Empowering subsidiaries to independently operate and allowing them to freely absorb external knowledge will help subsidiaries increase their innovation and enhance their competitive advantages through the transformation and application of knowledge (Beugelsdijk et al., 2017). MNEs will not only make use of their existing capabilities but also explore the landlord market through their subsidiaries. When the market changes, there are many market opportunities. The market needs subsidiaries to take the initiative to develop. Therefore, when the market is dynamic and changing, it is necessary for subsidiaries to have the autonomy to absorb external capabilities and then improve the comprehensive efficiency of enterprises so that subsidiaries have sustained advantages in the host country market.

Furthermore, although subsidiaries can reduce uncertainty through upstream and downstream links, they will experience the knowledge spillover risks in knowledge diffusion (Liu et al., 2014). While linking suppliers and customers can help the circulation of the knowledge about products, technologies or processes, it is possible for knowledge to be duplicated and imitated (Perri et al., 2013). This is because upstream and downstream linkages are not exclusive to an enterprise and are often just one segment of the linkages. When linkages exist, knowledge spillovers from international expansion will occur. Linkages between subsidiaries in the market are potentially important channels for knowledge diffusion (Santangelo, 2012). Li et al. (2018) also pointed out that spillover phenomena will appear in industry. Compared with the horizontal links of competitors, the vertical links of suppliers have obvious spillover effects. To avoid the outflow of key capabilities or information, the degree of subsidiary autonomy will be reduced (see Figure 1). Therefore, MNEs can use centralized ownership advantages to manage subsidiaries (Giroud et al., 2014) or incorporate subsidiaries into global strategies using cross-border strategies and organizational design to mitigate spillover effects (Marin \& Bell, 2006).

Second, springboard intentions have a significant negative effect on subsidiary autonomy, which means that the greater the springboard intention is, the less autonomy will be granted, which is inconsistent with the hypothesis. The possible reason is that when a subsidiary is an executive representative of an overseas investment, the degree of autonomy varies according 
to the global vision and strategy of the headquarters. When the headquarters wants to make up for its competitive disadvantage, it will regard overseas expansion as an important multipoint competition strategy. At this time, the subsidiary will be the focus of the global operations, and so headquarters will give autonomy to provide the subsidiary with an important strategic role (Birkinshaw, 1997; Shukla \& Mital, 2018). However, the purpose of such authorization is to give priority to the execution of headquarters' strategies by subsidiaries. When the subsidiary just wants to cooperate with the headquarters' policies, this strategy will negatively influence the subsidiary's cooperation with the headquarters' policy. Under such conditions, subsidiaries believe that although they have autonomy as a springboard strategy, they are only cooperating with the headquarters' plans (Chiao \& Ying, 2013). In other words, the implementation of a springboard strategy will reduce subsidiary autonomy so that subsidiaries can be fully integrated within the enterprise.

Third, the relationship between a springboard strategy and autonomy will ease the original negative relationship because of the vertical linkages. Such a result shows that when the enterprise applies the springboard strategy, it will reduce subsidiary autonomy in order to integrate subsidiaries into the overall strategy. However, when subsidiaries have vertical integration, perhaps the headquarters will think that subsidiaries are more or less similar to the host country when they have local linkages; and when they truly need help in business, they can also rely on this social capital (Santangelo, 2012); therefore, there will be some autonomy. If we add the results of the mediating variables, it is clearer that once the vertical integration relationship is included, subsidiaries will have "real" free energy to determine strategies to increase the degree of absorptive capacity. Although the final result of the moderating is weak, it is different from the direct relationship inference, and this result can provide different theoretical arguments.

\subsection{Managerial implications}

This study also provides important managerial implications. First, most studies agree that positive benefits can be achieved through empowerment and autonomy in management. Peter Drucker and Jeffrey Pfeffer both agree that autonomy is related to innovation and that empowerment motivates them to seek new skills and knowledge. However, many companies tend to use a high-control model because managers believe that their employees (or units) lack the motivation to participate and are not focused on what they should concentrate on. Bartlett and Ghoshal (2002) argue that this is because companies use overly simple and inappropriate management methods. Managers should formulate a set of management models that are suitable for enterprises and set rules for the cooperation between units and employees. Only in this kind of business environment can enterprises create the greatest driving force for business operations. Combined with this argument, control and autonomy should not be two mutually exclusive management strategies, but should include freedom under control and control within autonomy. For example, as Netflix and Alaska Airlines both know, when the market has growth opportunities, supporting the actions of their units and maximizing their benefits from free decision-making power is an important strategy for enterprises to develop competitive advantages. Alaska Airlines believes that the reason for the need to give local units autonomous decision-making power is that they need enough knowledge and space to 
make consistent decisions with organizational needs and plans when in that environment. If everything has to be approved, the units will not be able to maximize their effectiveness. Under the premise of definite goal setting and the internalization of standards, the largest competitive advantages from autonomy will not deviate from the direction of enterprises. Autonomy is important to subsidiaries and more influential to the headquarters' global strategy (Weng \& Cheng, 2019). Therefore, within the framework of the goal of the global expansion of MNEs, the degree of autonomy can play a more important role in the value of autonomy.

Second, the more competitive that a market is, the more room it should give subsidiaries to make decisions, which will help them absorb the desired capabilities. Due to the competition from globalization, the demand of the market is constantly changing and competitive pressures are increasing day by day. If the decision-making power is given to the subsidiaries on the spot, the local ability from the environment of the host country helps to improve the context-specific competence of the subsidiaries and the efficiency of responding to local needs. Of course, headquarters should also pay attention to whether there will be enterprise capability and information spillover when the subsidiary is in contact with the upstream and downstream portions. For example, La Kaffa International Co. has developed in the international market and, even in the face of fierce market competition, they still are located in 37 countries. Overseas subsidiaries have the power to find local suppliers and absorb local knowledge to expand their markets in the development process. In Australia, La Kaffa International Co. has absorbed local knowledge and formulated the best marketing strategy so that the bottlenecks among the original 55 branches grew to more than 100. However, not every upstream and downstream cooperative endeavor benefits La Kaffa International Co. It suffered operating losses in subsequent disputes over the use of unproven raw materials by its subsidiaries in Malaysia. Therefore, in the case of market competition, even if subsidiaries are given autonomy, the headquarters should also manage them within a reasonable range to ensure that subsidiary autonomy results in positive profits to the enterprise group so that when MNEs operate overseas, they can create with appropriate management strategies to acquire the greatest global advantages.

\subsection{Limitations and future research}

This study had five limitations and directions for future research. First, since the sample is of Taiwanese subsidiaries, it may be inferred that the relationship that is established here between MNEs and their subsidiaries is only applicable to Asia. Samples from different regions should be collected in the future, such as subsidiaries in the Western world or developed and developing countries. Second, primary data are used in this study, and different measurement methods can be used in the future to expand the management implications. Third, the moderating variable is only used in the relationship between market conditions and springboard intentions, but vertical linkages should also impact the absorptive capacity of subsidiaries. In the future, researchers should diversify the use of the moderating variable to make the theoretical contributions of the absorptive capacity more obvious. Fourth, this study validates the mediating effect of autonomy, but the connotation of autonomy can include management centralization. In the future, autonomy can be subdivided in more detail, 
and the more complete content can enrich the conceptual significance of autonomy. Finally, because linear structure analysis is used in this study, the errors are included in the measurement model, and so the control variables are not used in this study. In the future, under the premise of minimizing errors, control variables can be added to confirm the stability of the theoretical model.

\section{Notes}

Note 1. In order to measure the stability and explanatory power, this study adopts Perri et al. (2013) and asks subsidiaries to answer the relationship between "two suppliers" and "two customers". After collecting the data, the average values are added to obtain the corresponding degree of vertical links of subsidiaries.

Note 2. In this study, control variables were not included in the analysis. The main reason is that the error terms have been taken into account in the derivation of the linear structure measurement model. If the model is simplified, it will be helpful for appropriately matching data. Prior studies have been based on a theoretical model of uncontrolled variables. Therefore, the results that are obtained from the analysis of linear structure model with uncontrolled variables are explanatory.

\section{References}

Andersson, U., Forsgren, M., \& Holm, U. (2002). The strategic impact of external networks: subsidiary performance and competence development in the multinational corporation. Strategic Management Journal, 23(11), 979-996. https://doi.org/10.1002/smj.267

Autio, E., Sapienza, H. J., \& Almeida, J. G. (2000). Effects of age at entry, knowledge intensity, and imitability on international growth. Academy of Management Journal, 43(5), 909-1014. https://doi.org/10.2307/1556419

Bagozzi, R. P., Yi, Y., \& Phillips, L. W. (1991). Assessing construct validity in organizational research. Administrative Science Quarterly, 36(3), 421-458. https://doi.org/10.2307/2393203

Bartlett, C. A., \& Ghoshal, S. (2002). Managing Across Borders: The Transnational Solution (2 ed.). Boston, MA: Harvard Business Review Press.

Bartlett, C., \& Beamish, P. (2013). Transnational Management: Text, Cases \& Readings in Cross-Border Management (7 ed.): McGraw-Hill/Irwin.

Beugelsdijk, S., Nell, P. C., \& Ambos, B. (2017). When do distance effects become empirically observable? an investigation in the context of headquarters value creation for subsidiaries. Journal of International Management, 23(3), 255-267. https://doi.org/10.1016/j.intman.2017.03.002

Birkinshaw, J. M. (1997). Entrepreneurship in multinational corporation: the characteristics of subsidiary initiatives. Strategic Management Journal, 18(3), 207-229. https://doi.org/10.1002/(SICI)1097-0266(199703)18:3<207::AID-SMJ864>3.0.CO;2-Q

Birkinshaw, J. M., \& Fry, N. (1998). Subsidiary initiatives to develop new markets. Sloan Management Review, 39(3), 51-61.

Birkinshaw, J., Ghoshal, S., Markides, C. C., Stopford, J., \& Yip, G. (2007). The Future of the Multinational Company: Wiley.

Bollen, K. A. (1989). Structural Equations with Latent Variables. New York: John Wiley. 
https://doi.org/10.1002/9781118619179

Chen, J. L. C., Maitland, E., \& Nicholas, S. (2009). Managing Subsidiary Dynamics Headquarters Role, Capability Development, and China Strategy: Emerald Group Publishing Limited. https://doi.org/10.1108/S1571-5027(2009)22

Chiao, Y.-C., \& Ying, K.-P. (2013). Network effect and subsidiary autonomy in multinational corporations: an investigation of Taiwanese subsidiaries. International Business Review, 22(4), 652-662. https://doi.org/10.1016/j.ibusrev.2012.10.001

Clark, K., \& Ramachandran, I. (2019). Subsidiary Entrepreneurship and Entrepreneurial Opportunity: an Institutional Perspective. Journal of International Management, 25(1), 37-50. https://doi.org/10.1016/j.intman.2018.06.001

Cohen, W. M., \& Levinthal, D. A. (1990). Absorptive capacity: a new perspective on learning and innovation. Administrative Science Quarterly, 35(1), 128-152. https://doi.org/10.2307/2393553

Cui, T., Wu, Y., \& Tong, Y. (2018). Exploring ideation and implementation openness in open innovation projects: IT-enabled absorptive capacity perspective. Information \& Management, 55(5), 576-587. https://doi.org/10.1016/j.im.2017.12.002

Dadashpoor, H., \& Yousefi, Z. (2018). Centralization or decentralization? a review on the effects of information and communication technology on urban spatial structure. Cities, 78, 194-205. https://doi.org/10.1016/j.cities.2018.02.013

Decreton, B., Nell, P. C., \& Stea, D. (2019). Headquarters involvement, socialization, and entrepreneurial behaviors in MNC subsidiaries. Long Range Planning, 52(4), 101839. https://doi.org/10.1016/j.lrp.2018.05.005

Dikova, D., Arjen van, W., \& Parker, S. (2017). Capability, environment and internationalization fit, and financial and marketing performance of MNEs' foreign subsidiaries. Cross Cultural \& Strategic Management, 24(3), 405-435. https://doi.org/10.1108/CCSM-01-2016-0003

Doz, Y. L., \& Prahalad, C. K. (1991). Managing DMNCs: A search for a new paradigm. Strategic Management Journal, 12(S1), 145-163. https://doi.org/10.1002/smj.4250120911

Doz, Y. L., Santos, J., \& Williamson, P. (2001). From Global to Metanational: How Companies Win in the Knowledge Economy: Harvard Business Review Press. https://doi.org/10.1145/503351.503119

Dunning, J. H. (1993). Multinational Enterprises and the Global Economy: Addison-Wesley.

Efrat, K., Hughes, P., Nemkova, E., Souchon, A. L., \& Sy-Changco, J. (2018). Leveraging of dynamic export capabilities for competitive advantage and performance consequences: evidence from China. Journal of Business Research, 84(3), 114-124. https://doi.org/10.1016/j.jbusres.2017.11.018

Eisenhardt, K. M., \& Martin, J. A. (2000). Dynamic capabilities: what are they? Strategic Management Journal, 21(10-11), 1105-1121. https://doi.org/10.1002/1097-0266(200010/11)21:10/11<1105::AID-SMJ133>3.0.CO;2-E

Enright, M. J., \& Subramanian, V. (2007). An organizing framework for MNC subsidiary typologies. Management International Review, 47(6), 895-924. 
https://doi.org/10.1007/s11575-007-0057-6

Filatotchev, I., \& Piesse, J. (2009). R\&D, internationalization and growth of newly listed firms: European evidence. Journal of International Business Studies, 40(8), 1260-1276. https://doi.org/10.1057/jibs.2009.18

Fornell, C., \& Larcker, D. F. (1981). Evaluating structural equation models with unobservable variables and measurement error. Journal of Marketing Research, 18(1), 39-50. https://doi.org/10.1177/002224378101800104

Frost, T. S., Birkinshaw, J. M., \& Ensign, P. C. (2002). Centers of excellence in multinational corporations. Strategic Management Journal, 23(11), 997-1018. https://doi.org/10.1002/smj.273

Gates, S. (1995). Strategic Alliances: Guidelines for Successful Management: Conference Board.

Gates, S. R., \& Egelhoff, W. G. (1986). Centralization in headquarters-subsidiary relationships. Journal of International Business Studies, 17(2), 71-92. https://doi.org/10.1057/palgrave.jibs.8490425

Ghoshal, S., \& Bartlett, C. A. (1990). The multinational corporation as an interorganizational network. Academy of Management Review, 15(4), 603-625. https://doi.org/10.5465/amr.1990.4310825

Giroud, A., Yoo, J. H., \& Yamin, M. (2014). Foreign subsidiaries' internal and external R\&D cooperation in South Korea: explanatory factors and interaction. Asian Business \& Management, 13(3), 227-256. https://doi.org/10.1057/abm.2014.8

Glaister, K. W., Husan, R., \& Buckley, P. J. (2003). Decision-making autonomy in UK international equity joint ventures. British Journal of Management, 14(4), 305-322. https://doi.org/10.1111/j.1467-8551.2003.00381.x

Grewal, R., Chandrashekaran, M., \& Dwyer, F. R. (2008). Navigating local environments with global strategies: a contingency model of multinational subsidiary performance. Marketing Science, 27(5), 886-902. https://doi.org/10.1287/mksc.1070.0353

Gulati, R., Nohria, N., \& Zaheer, A. (2000). Strategic networks. Strategic Management Journal, 21(3), 203-215. https://doi.org/10.1002/(SICI)1097-0266(200003)21:3<203::AID-SMJ102>3.0.CO;2-K Gupta, A. K., \& Govindarajan, V. (2000). Knowledge flows within multinational corporations. Strategic Management Journal, 21(4), 473-496. https://doi.org/10.1002/(SICI)1097-0266(200004)21:4<473::AID-SMJ84>3.0.CO;2-I

Hada, M., Grewal, R., \& Chandrashekaran, M. (2013). MNC subsidiary channel relationships as extended links: implications of global strategies. Journal International Business Studies, 44(8), 787-812. https://doi.org/10.1057/jibs.2013.34

He, Z.-L., \& Wong, P.-K. (2004). Exploration vs. exploitation: an empirical test of the ambidexterity hypothesis. Organization Science, 15(4), 481-484. https://doi.org/10.1287/orsc.1040.0078

Hughes, M., Morgan, R. E., Ireland, R. D., \& Hughes, P. (2014). Social capital and learning advantages: a problem of absorptive capacity. Strategic Entrepreneurship Journal, 8(3), 
214-233. https://doi.org/10.1002/sej.1162

Jarillo, J. C., \& Martinez, J. I. (1990). Different roles for subsidiaries: the case of multinational corporations in Spain. Strategic Management Journal, 11(7), 501-512. https://doi.org/10.1002/smj.4250110702

Jayachandran, S., Sharma, S., Kaufman, P., \& Raman, P. (2005). The role of relational information processes and technology use in customer relationship management. Journal of Marketing, 69(4), 177-192. https://doi.org/10.1509/jmkg.2005.69.4.177

Jerez-Gómez, P., Céspedes-Lorente, J., \& Pérez-Valls, M. (2019). Do high-performance human resource practices work? the mediating role of organizational learning capability. Journal of Management and Organization, 25(2), 189-210. https://doi.org/10.1017/jmo.2017.55

Jindra, B., Giroud, A. 1., \& Scott-Kennel, J. (2009). Subsidiary roles, vertical linkages and economic development: lessons from transition economies. Journal of World Business, 44(2), 167-179. https://doi.org/10.1016/j.jwb.2008.05.006

Johanson, J., \& Vahlne, J. E. (1990). The mechanism of internationalisation. International Marketing Review, 7(4), 11-24. https://doi.org/10.1108/02651339010137414

Khanna, T., \& Palepu, K. G. (2010). Winning in Emerging Markets: A Road Map for Strategy and Execution: Harvard Business Review Press. https://doi.org/10.1177/0974173920100316

Klepper, S. (1996). Entry, exit, growth, and innovation over the product life cycle. American Economic Review, 86(3), 562-583.

Kumar, N., \& Puranam, P. (2011). Have you restructured for global success? Harvard Business Review, 89(10), 123-128.

Lane, P. J., Salk, J. E., \& Lyles, M. A. (2001). Absorptive capacity, learning, and performance in international joint ventures. Strategic Management Journal, 22(12), 1139-1161. https://doi.org/10.1002/smj.206

Li, Q., Xue, Q., Truong, Y., \& Xiong, J. (2018). MNCs' industrial linkages and environmental spillovers in emerging economies: the case of China. International Journal of Production Economics, 196, 346-355. https://doi.org/10.1016/j.ijpe.2017.12.008

Liu, X., Lu, J., \& Choi, S.-j. (2014). Bridging knowledge gaps: returnees and reverse knowledge spillovers from Chinese local firms to foreign firms. Management International Review, 54(2), 253-276. https://doi.org/10.1007/s11575-013-0185-0

Luo, Y., \& Tung, R. (2007). International expansion of emerging market enterprises: a springboard perspective. Journal of International Business Studies, 38(4), 481-498. https://doi.org/10.1057/palgrave.jibs.8400275

Marin, A., \& Bell, M. (2006). Technology spillovers from foreign direct investment (FDI): the active role of MNC subsidiaries in Argentina in the 1990s. Journal of Development Studies, 42(4), 678-697. https://doi.org/10.1080/00220380600682298

Mathews, J. A. (2002). Competitive advantages of the latecomer firm: a resource-based account of industrial catch-up strategies. Asia Pacific Journal of Management, 19(4), 467-488. https://doi.org/10.1023/A:1020586223665

Mathews, J. A. (2006). Dragon multinationals: new players in 21 st century globalization. 
Asia Pacific Journal of Management, 23(1), 5-27. https://doi.org/10.1007/s10490-006-6113-0

Newburry, W., \& Zeira, Y. (1999). Autonomy and effectiveness of equity international joint ventures: comparative analysis of Hungary and Britain. Journal of Management Studies, 36(2), 263-285. https://doi.org/10.1111/1467-6486.00136

Park, S. H., \& Luo, Y. (2001). Guanxi and organizational dynamics: organizational networking in Chinese firms. Strategic Management Journal, 22(5), 455-477. https://doi.org/10.1002/smj.167

Paterson, S. L., \& Brock, D. M. (2002). The development of subsidiary-management research: review and theoretical analysis. International Business Review, 11(2), 139-163. https://doi.org/10.1016/S0969-5931(01)00053-1

Perri, A., Andersson, U., Nell, P. C., \& Santangelo, G. D. (2013). Balancing the trade-off between learning prospects and spillover risks: MNC subsidiaries' vertical linkage patterns in developed countries. Journal of World Business, 48(4), 503-514. https://doi.org/10.1016/j.jwb.2012.09.006

Phene, A., Tallman, S., \& Almeida, P. (2012). When do acquisitions facilitate technological exploration and exploitation? Journal of Management, 38(3), 753-783.

Podsakoff, P. M., \& Organ, D. W. (1986). Self-reports in organizational research: problems and prospects. Journal of Management, 12(4), 531-544. https://doi.org/10.1177/014920638601200408

Ramamurti, R., \& Williamson, P. J. (2019). Rivalry between emerging-market MNEs and developed-country MNEs: Capability holes and the race to the future. Business Horizons, 62(2), 157-169. https://doi.org/10.1016/j.bushor.2018.11.001

Randolph, W. A., \& Sashkin, M. (2002). Can organizational empowerment work in multinational settings? Academy of Management Executive, 16(1), 102-115.

Roth, K., \& Morrison, A. J. (1992). Implementing global strategy: characteristics of global subsidiary mandates. Journal of International Business Studies, 23(4), 715-735. https://doi.org/10.1057/palgrave.jibs.8490285

Santangelo, G. D. (2012). The tension of information sharing: effects on subsidiary embeddedness. International Business Review, 21(2), 180-195. https://doi.org/10.1016/j.ibusrev.2011.01.004

Schleimer, S. C., \& Pedersen, T. (2013). The driving forces of subsidiary absorptive capacity. Journal of Management Studies, 50(4), 646-672. https://doi.org/10.1111/joms. 12010

Shukla, D. M., \& Mital, A. (2018). Effect of firm's diverse experiences on its alliance portfolio diversity: evidence from India. Journal of Management and Organization, 24(5), 748-772. https://doi.org/10.1017/jmo.2016.26

Song, M., Droge, C., Hanvanich, S., \& Calantone, R. (2005). Marketing and technology resource complementarity: an analysis of their interaction effect in two environmental contexts. Strategic Management Journal, 26(3), 259-276. https://doi.org/10.1002/smj.450

Song, S. (2014). Subsidiary divestment: the role of multinational flexibility. Management International Review, 54(1), 47-70. https://doi.org/10.1007/s11575-013-0198-8

Sun, J., Wang, S. L., \& Luo, Y. (2018). Strategic entry or strategic exit? international presence 


\section{Macrothink}

Journal of Management Research

ISSN 1941-899X 2020, Vol. 12, No. 1

by emerging economy enterprises. International Business Review, 27(2), 418-430. https://doi.org/10.1016/j.ibusrev.2017.09.009

Taggart, J. H. (1997). Autonomy and procedural justice: a framework for evaluating subsidiary strategy. Journal of International Business Studies, 28(1), 51-76. https://doi.org/10.1057/palgrave.jibs.8490093

Teece, D. J., Pisano, G., \& Shuen, A. (1997). Dynamic capabilities and strategic management. Strategic Management Journal, 18(7), 509-533. https://doi.org/10.1002/(SICI)1097-0266(199708)18:7<509::AID-SMJ882>3.0.CO;2-Z

Wang, S. L., Luo, Y., Lu, X., Sun, J., \& Maksimov, V. (2014). Autonomy delegation to foreign subsidiaries: an enabling mechanism for emerging-market multinationals. Journal of International Business Studies, 45(2), 111-130. https://doi.org/10.1057/jibs.2013.40

Washburn, N. T., \& Hunsaker, B. T. (2011). Finding great ideas in emerging markets. Harvard Business Review, 89(9), 115-120.

Weng, D. H., \& Cheng, H.-L. (2019). The more, the merrier? how a subsidiary's organizational identification with the MNE affects its initiative. Long Range Planning, 52(4), 101860. https://doi.org/10.1016/j.1rp.2018.11.004

Williamson, P. J., \& Zeng, M. (2009). Value-for-money strategies for recessionary times. Harvard Business Review, 87(3), 66-74.

$\mathrm{Wu}, \mathrm{J} .$, \& Chen, X. (2014). Home country institutional environments and foreign expansion of emerging market firms. International Business Review, 23(5), 862-872. https://doi.org/10.1016/j.ibusrev.2014.01.004

Yamin, M., \& Andersson, U. (2011). Subsidiary importance in the MNC: what role does internal embeddedness play? International Business Review, 20(2), 151-162. https://doi.org/10.1016/j.ibusrev.2010.07.005

Zahra, S. A., \& George, G. (2002). Absorptive capacity: a review, reconceptualization, and extension. Academy of Management Review, 27(2), 185-203. https://doi.org/10.5465/amr.2002.6587995

Zhang, S., Kwok, R. C.-W., Lowry, P. B., Liu, Z., \& Wu, J. (2019). The influence of role stress on self-disclosure on social networking sites: a conservation of resources perspective. Information and Management. https://doi.org/10.1016/j.im.2019.02.002 


\section{Appendix}

\begin{tabular}{|c|c|c|}
\hline Construct & Items & Factor loading \\
\hline Market conditions & $\begin{array}{l}\text { The extent of product changes is due to the } \\
\text { relationship between market competition. } \\
\text { The magnitude of a strategy change is due to the } \\
\text { relationship between market competition. } \\
\text { This market is beneficial to us in terms of its } \\
\text { statutory provisions. } \\
\text { The market in which the company is located is } \\
\text { changing rapidly. }\end{array}$ & $\begin{array}{l}0.78 \\
0.86 \\
0.74\end{array}$ \\
\hline $\begin{array}{l}\text { Springboard } \\
\text { intention }\end{array}$ & $\begin{array}{l}\text { Our objective in expanding overseas markets is to }[\ldots] \\
\text { acquire new technologies. } \\
\text { increase brand interest. } \\
\text { improve reputation. } \\
\text { obtain good talent. }\end{array}$ & $\begin{array}{l}0.63 \\
0.86 \\
0.70 \\
0.74\end{array}$ \\
\hline $\begin{array}{l}\text { Subsidiary } \\
\text { autonomy }\end{array}$ & $\begin{array}{l}\text { The headquarters gives us a certain degree of freedom in } \\
{[\ldots]} \\
\text {... decision-making. } \\
\text { product development. } \\
\text { capacity expansion. } \\
\text { budgeting. } \\
\text { - employing manpower. }\end{array}$ & $\begin{array}{l}0.75 \\
0.82 \\
0.82 \\
0.84 \\
0.86\end{array}$ \\
\hline $\begin{array}{l}\text { Knowledge } \\
\text { identification }\end{array}$ & $\begin{array}{l}\text { We have introduced new technological capabilities } \\
\text { from the market. } \\
\text { We can quickly access information on market } \\
\text { changes. } \\
\text { We have encouraged all employees to acquire } \\
\text { knowledge through various channels. }\end{array}$ & $\begin{array}{l}0.84 \\
0.88\end{array}$ \\
\hline $\begin{array}{l}\text { Knowledge } \\
\text { understanding }\end{array}$ & $\begin{array}{l}\text { We can translate the acquired new knowledge into } \\
\text { what employees understand. } \\
\text { We have the ability to identify areas for } \\
\text { improvement in acquired new knowledge. } \\
\text { We have specialized agencies (or personnel) } \\
\text { responsible for promoting the absorption of } \\
\text { knowledge. }\end{array}$ & $\begin{array}{l}0.86 \\
0.76\end{array}$ \\
\hline $\begin{array}{l}\text { Knowledge } \\
\text { application }\end{array}$ & $\begin{array}{l}\text { We can make significant improvements in the } \\
\text { knowledge that we acquire. } \\
\text { We are willing to adopt new business methods to } \\
\text { make operations more efficient. } \\
\text { We can combine the acquired new knowledge to } \\
\text { develop new services. }\end{array}$ & $\begin{array}{l}0.80 \\
0.69\end{array}$ \\
\hline Vertical linkages & $\begin{array}{l}\text { Dependence of the company on product technology. } \\
\text { Dependence of the company on process technology } \\
\text { Dependence of the company on the overall } \\
\text { business. } \\
\text { Number of enterprise functions involved in } \\
\text { interactive partnerships within the company.* }\end{array}$ & $\begin{array}{l}0.67 \\
0.69 \\
0.71\end{array}$ \\
\hline
\end{tabular}

* In this study, senior management, administrative departments, procurement departments, sales departments, production departments (technicians), and R\&D departments were selected as the management functions that participate in the linkages, which is taken from Andersson et al. (2002). 